\title{
Translation and Untranslatability in the Poetry of Dennis Brutus and Keorapetse Kgositsile
}

\section{Karin Berkman}

https://orcid.org/0000-0002-2834-9779

Hebrew University of Jerusalem

karin.berkman@mail.huji.ac.il

Abstract

This paper traces aspects of the history of the trope of translation, familiar both in critical works that address South African literature and in South African literary texts, in relation to two poems by the black South African poets, Dennis Brutus and Keorapetse

Kgositsile. It considers their insinuation of untranslated or translated Afrikaans into an English text as a radical poetic strategy that both reinforces and disrupts established paradigms of the trope of translation. The paper focuses on the poems: "Here of the Things I Mark," by Dennis Brutus, published in 1978 at the height of apartheid rule and the post-apartheid poem, "No Serenity Here" by Keorapetse Kgositsile, published in 2009. I consider the ways in which Brutus both confirms and subverts the identification of Afrikaans as the language of apartheid and suggest that his use of Afrikaans constitutes a practice of resistance that breaches the rigid segregations enforced by apartheid and exposes their permeability. In a close reading of Kgositsile's "No Serenity Here," I relate to his use of the trope of translation and of untranslated Afrikaans within the poem as a radical critique both of European colonization and of post-apartheid South Africa, still unliberated from the perverse legacies of that colonization. In parsing the anomalies of Brutus and Kgositsile's use of Afrikaans in these poems, I map possible future directions for the historiography of the trope of translation in South African poetics.

Keywords: translation; untranslatability; Dennis Brutus; Keorapetse Kgositsile; Afrikaans; apartheid 


\section{South African histories of translation}

The twenty first century has been heralded by Susan Bassnett $(2014,1)$ as "the great age of translation." In the context of rapidly accelerating globalization, the realignment of borders, and the mass migrations and exiles that have set people into motion and undermined notions of territorial and cultural discreteness, the notion of translation as an increasingly imperative linguistic practice and as a particularly dense metaphor for both displacement and accommodation has become the focus of critical scrutiny across a variety of disciplines. This is widely borne out by a large corpus of scholarship that cannot be addressed in full here, but I mention briefly the wide impact of the connection that Homi Bhabha (1994) draws between the transnational and the translational, of Susan Bassnett's (2014) positing of the post-colony as a translation of a colonial original and of Salman Rushdie's (1991) notion of translated man.

Almost all considerations of the notion of translation alternate between the two senses of the sign and their mutual imbrication: translation is both the transferal of meaning across languages and transition, the bearing across and transgression of borders and boundaries. Indeed, the Oxford English Dictionary lists “exile” as a synonym for "translate" (Oxford English Dictionary). In South Africa the turn to notions of linguistic translation and of cultural translation, in the sense of displacement, the passage across, and breaching of cultural barriers, has a protracted and distinct historiography.

During apartheid rule, the trope figures in South Africa's literary imagination as a matrix around which profound anxieties cluster: the urgency and singularity of its use is both a response to, and an index of the perceived exceptionalism of the practice of apartheid. In post-apartheid South Africa, the trope shifts, now linked to transnational investigations of translation and at the same time acquiring new nuances that are highly distinctive. Its association with notions of transferal and transformation makes it acutely relevant to the specifics of South Africa's contemplation of its own transitional status, and the painful processes of national transfiguration. The passage to post-apartheid expresses itself often both literally and figuratively as the learning and comprehension of new languages, as an acquisition of the capacity to translate.

Of the various critical attempts to relate the question of the trope of translation to the ideological determinants of apartheid, one early and influential example is the work of Steven Gray, one of South Africa's most prominent literary critics and a writer of critically acclaimed works of poetry, prose and drama. Gray's article (1989) “Some problems of writing historiography in 
Southern Africa" examines the difficulties of defining the nature of South African literature and of determining the criteria of literary merit in relation to two literary projects: the collaborative chapter written by Gray, Tim Couzens, and Ampie Coetzee for Albert Gerard's History of African Literatures in European Languages, and Gray's editing of The Penguin Book of Southern African Short Stories. In the first project, work was divided among the collaborators so that Gray was responsible for "white” English," Couzens for "black" English and Coetzee for Netherlands-Afrikaans. Looking back at this effort, ameliorative in its own context, Gray (1989, 19) confesses painfully to the "shadow of apartheid" that falls across the work. The division by race and language, in what Gray ironically identifies as the extension of the Group Areas Act to literature, thus replicates apartheid-era principles of segregation as categories of value. In an attempt to avoid the wounding distortions of racialized classifications, Gray proposes an alternate paradigm that contests this logic: he reframes the unique features of the South Africa artist and the attribution of literary value within a notion of translation, here conceived as a mode of resistance to the strictures of apartheid, manifesting itself in defiant practices of plurality, negotiation, slippage and syncretism:

Therefore our system does have some norms peculiar to it. For one, the writer is always forced into a position of having to negotiate between extremes, into crossing the language-colour barrier; he or she can only be a syncretist and hybridiser. And therefore the basic act of writing is one of carrying information across one or another sociopolitical barrier, literally of 'trading' - and that is probably the writer's source of greatness. I propose, thus, a new identikit portrait: the writer exists at any of several boundaries (not at the centre of one self-enclosed group); his or her act of making literature is part of transferring data across that boundary, from one audience to another — an act which in the broadest sense may be termed 'translation'. (Gray 1989, 20-21, emphasis in original)

In Gray's construction of South African literary culture, apartheid is construed as inimical to these acts of mixing as resistance. Instead, it actively imposes practices of non-translation, converting language itself into a site of dispossession and segregation. Gray $(1989,19)$ records his own inevitable co-option in the act of covert non-translation that dogs the collaborative project: "I have to note (with shame) that the other literatures of South Africa, those in the autochthonous African languages, had no place even in our supposedly progressive schedule of 
the historiographical." The ellipsis in the critical text thus rehearses the ways in which African languages remain both literally and figuratively unvoiced, untranslated and incomprehensible in the schemata imposed by apartheid.

Gray represents his editorship of The Penguin Book of Southern African Short Stories partially as a reparative act, one which foregrounds the poetics of translation as dissidence, as undermining explicitly or tacitly the maintenance of hermetically sealed, static racial stratifications under apartheid. Noting the frequency with which instances of both linguistic translation and translation as metonym for cultural transition feature in the collection, he outlines as a salient editorial policy the decision to "select stories which reflected cross-lingual, cross-sub-group encounters, to demonstrate the thesis that, however unfashionable this may seem, this has always been, and still is, the main concern of all writers within the system" (Gray 1989, 22, emphasis in original). This is a particularly comprehensive delineation of the trope of translation as underlying literary production in South Africa.

The relocation of the trope of translation in relation to cultural production in post- apartheid South Africa produces a shift of emphasis: if apartheid remains identified with refusals and failures of translation, in the new South Africa, translation functions less as a metonym for resistance than a methodology of expiation and rehabilitation, directed towards a bridging and healing of the wounding separations of apartheid.

The possibilities of restitutive translation, even of translation as ethic, are made manifest in South Africa's new constitution, promulgated in 1996. Defining language rights as amongst the most important of South Africa's civil rights, the constitution aims at repairing the injury of the designation of two official languages under apartheid, Afrikaans and English — ostensibly the languages of white speakers - and the corresponding denial of any status to all black languages and by extension to their speakers. In the first article of the new constitution, the equivalence of South Africa's eleven languages is entrenched and protected. The promise of a reparative multilingualism is given pre-emptive validity in the preamble to the constitution which ends with six translations of "God bless Africa." These multiple construals are both a benediction that confirms continental solidarity and repeals South Africa's shameful exceptionality, and a citation of "Nkosi Sikelel' iAfrika," the anthem of the liberation struggle. South Africa's post-apartheid national anthem is designated in section 4 of the constitution, a slightly awkward amalgam in which the isiXhosa, isiZulu and Sesotho versions of Nkosi Sikelel' iAfrika are yoked together in 
an uneasy polyphony with the Afrikaans and English stanzas of "Die Stem," the national anthem under apartheid. The new anthem thus carries the symbolic weight of a conception of translation as a strategy of reconciliation.

South Africa's past monologic insistence on linguistic integrity, a reprise of apartheid's prohibition of miscegenation, and its recoil from the implications of hybridity is replaced by the generative exchange implied by translation. As scholars and writers including Antjie Krog (1998, 2003, 2009), Mark Sanders (2000), Louise Bethlehem (2007) and Sam Raditlhalo (2009), amongst others, have noted, the Truth and Reconciliation Commission encouraged witnesses to the atrocities of apartheid to testify in their own languages, and employed cadres of simultaneous translators to relay the testimony. Translation as event and as performance was thus brought forcefully both into the public sphere and into private and intimate contexts, implicating it profoundly in the processes of commemoration, reparation and reconciliation deemed imperative in the new South Africa. This transformation of the trope is prominent in the work of Krog $(1998,2009)$ both in her meditation on the workings of the TRC in Country of My Skull and as the dominant motif of A Change of Tongue. Questions on the nature of translation lie at the heart of her collaborative work, written together with Nosisi Mpolweni and Kopano Ratele, There Was this Goat (2009). Krog is herself a poet, journalist and translator, lauded for the sensitivity and depth of her translations into Afrikaans, (including the translation of Nelson Mandela's autobiography, Long Walk to Freedom.) Krog (2003, 225) insists on the inseparability of linguistic and cultural translation. Considering the effect of the TRC, she states: "After three centuries of silence South Africans could daily hear the black voice talking and being translated; for the first time white South Africans could hear and listen. Through translation we could access our deepest emotions and feelings." In A Change of Tongue, contemplating the notion of translation beyond its extreme public apotheosis in the TRC, Krog $(2009,270)$ locates in its praxis a mode of being whose implications transcend the local exigencies of post- apartheid South Africa to become a global, even existential imperative: "Translation is essential if we are to learn to live together on this planet. We have to begin to translate one another."

Krog's equation of translation with an achieved responsiveness, with mutuality and regeneration and has been problematized by theorists like Leon de Kock (2012) and Carli Coetzee (2013).

Both point to the ways in which the notion of translation carries colonial legacies of violence and coercion that cannot be erased by Krog's ameliorative model. Their reluctance to adopt 
reparative translation as a kind of master trope underlying post-apartheid South African writing and indeed relations of community and commonality in the new South Africa is equally a reaction against the ways in which the idea of translation tends to elide difference to serve a utopian vision of coherence. Both de Kock and Coetzee note a near inevitable impulse to perpetuate hegemonic structures in translation: English remains recalcitrantly the "target language" and the persistent asymmetries of translations which may privilege one language over another lead to the risk of restaging, even perpetuating inequality.

De Kock, $(2012$, 743), drawing on the writings of Zoë Wicomb, points to the pitfalls of the trope and suggests a model of interstitiality, of a "seamed" or scarred translation that continues to attest to the past. The "transitive-translational seam" $(2012,743)$ maintains the dis-ease of difference and contests the palliative, incorporative agency of translation with its tendency to suppress the history of injury. Responding to Gray's attempt to define the parameters of South African literature, de Kock provides a complementary model that retains the pertinence and importance of translation, while complicating the emphases of Gray's argument.

Coetzee's (2013) critique of translation substitutes "accent" for translation. Pointing to the limitations of the trope, and the need "to demythologize translation as a metaphor for greater understanding and identification" (2013, xiv), she frames "accent", a marker of linguistic difference, as incorporating acts of non-translation into paradigms of translation. Aborted, failed or repudiated acts of translation impede the smooth transferal of meaning implied by translation. Coetzee thus validates miscomprehensions and refusals to transfer meaning as a means of communication that does not entail self-suppression or self-distortion in the service of an ideal of concord. Both Coetzee and de Kock's critiques do not reject the premise of translation as a mode of crossing: while they broaden the definitions of translation, partly in order to historicize the passages it inscribes, they maintain the components of a translative model, that is, of translation, either achieved or aborted, as a primary feature of post- apartheid cultural practice and as a means of limning the features of new political processes.

In South Africa the problematics of translation, the untranslated, translatability and untranslatabilty ${ }^{1}$ adhere particularly to Afrikaans, the language wholly identified with the

\footnotetext{
${ }^{1}$ The term "untranslatability" has acquired wide currency in the field of world literature, particularly in the aftermath of the publication of Emily Apter's study Against World Literature: on the Politics of Untranslatability (2013). This article retains Apter's emphasis on untranslatability as privileging incommensurability over equivalence, without recourse to the context of world literature.
} 
structures and practices of apartheid. In Jacques Derrida's renowned prediction of apartheid's demise, "Racism's Last Word" (1985), written for the catalogue of the exhibition “Art contre/ against apartheid," metaphors of translation and untranslatabilty are put into play: Derrida posits that the works of art that denounce apartheid engage in an act of empathic translation, "speak[ing] the other's language without renouncing their own": their capacity to translate is ranged against apartheid as "the untranslatable idiom." $(1985,294)$ Articulating the shamefulness that adheres to the signifier and which renders it a kind of linguistic pariah, Derrida $(1985,292)$ states: " no tongue has ever translated this name - as if all the languages of the world were defending themselves, shutting their mouths against a sinister incorporation of the thing by means of the word, as if all tongues were refusing to give an equivalent, refusing to let themselves be contaminated through the contagious hospitality of the word-for- word." Because the name "apartheid" is always insistently and irredeemably in Afrikaans, because the language hosts the corrupted sign, it is itself rendered untranslatable.

Within South Africa, in the literature of resistance, a fierce opprobrium attaches to the language: ${ }^{2}$ South African writers, including those for whom Afrikaans is a first language, repeatedly declare their wariness of the contaminant of apartheid that seeps into the language. In Breyten Breytenbach's poem $(1978,95)$ on the revival of Afrikaans, "The Struggle for the Taal," violence is made systemic, inscribed in its very langue: "We bring you the grammar of violence / and the syntax of destruction- / from the tradition of our firearms / you will hear the verbs of retribution stuttering." Krog $(1998,238)$ articulates the anguish of the corruption of her mother tongue: "How do I live with the fact that all the words used to humiliate, all the orders to kill belonged to the language of my heart."

Hein Willemse, anti-apartheid activist and critic and South Africa's most prominent scholar of black writers writing in Afrikaans, reminds us that Afrikaans' inscription of apartheid's violations is more than a literary construct: the decision to make Afrikaans the language of instruction precipitated the student uprising of 1976. It is this violent history of the language, its mobilization as weapon against the non-citizens of South Africa, that prompts Willemse's assertion (1987, 242): "No Black Afrikaans writer can be spared the intellectual anguish of

\footnotetext{
${ }^{2}$ Neville Alexander, the renowned anti-apartheid activist and linguist, warns against this fetishization of Afrikaans, drily pointing out that "to equate some of the attitudes of some of the mother tongue speakers of a language with the language itself is to make a rudimentary but potentially dangerous category mistake" $(2009,2)$.
} 
rationalizing his choice of language." Despite this, the critique of an unmeditated association between Afrikaans and apartheid is made most succinctly by Willemse who argues that to define Afrikaans exclusively as the language of the oppressor is to ratify a construct that effaces the possibility of black agency within the language, and to become complicit in the Afrikaners' consecration of a White and Christian Afrikaans. Willemse (2015 1) emphatically defines Afrikaans as a creole, contesting the claims to linguistic purity and to a European provenance made by Afrikaner nationalists intent on effacing the founding influence of black speakers of the language. His insistence on Afrikaans as a language that "bears the imprint of a fierce tradition of anti-imperialism, anti-colonialism, of an all-embracing humanism and anti-apartheid activism" refutes the more limited view of Afrikaans as the idiom of apartheid. In marking the language's multi-faceted history and in recuperating the occluded voices of "many South Africans of every hue [who] have contributed to its formation and development," Willemse (2015 1) echoes Grey's emphasis on hybridity and syncretism as countering apartheid's monolithic narratives. ${ }^{3}$

$\underline{2}$

\section{"A Bitter Word": The translated/ untranslated in the poetry of Dennis Brutus}

Like Willemse, Brutus contests a white proprietorship of Afrikaans. His use of Afrikaans signs, particularly in the poem which is the focus of this paper, unsettles the paradigms that cast Afrikaans as the vernacular of apartheid, and challenges the oppositional positioning of translation as a practice of resistance and failed or refused translation as a metaphor for the workings of apartheid.

Dennis Brutus was born in Rhodesia in 1924. After his family's relocation to the South African city, Port Elizabeth in 1928, he was classified as Coloured (mixed race) by the South African regime. Brutus' prominence as an anti- apartheid activist, his exposure of flagrant racial inequality in South African sport and his active promotion of a sports boycott led to his banning. In the aftermath of his contravention of his banning order, he was imprisoned on Robben Island in 1963, and on his release, went into exile in 1965. Brutus' poems foreground the political role

${ }_{3}^{3}$ The validation of Afrikaans' black history and the role of its many speakers has come to the fore in post-apartheid South Africa, Critical attention is increasingly being paid to Kaaps, the Cape dialect of Afrikaans, spoken, in the discredited nomenclature of apartheid, by "Coloured" South Africans. Christopher Stroud and Quentin Williams (2017 180) draw attention to the "multivocal imaginary" of Afrikaans. Menán Van Heerden's consideration of the multimedia theatre production Afrikaaps examines the ways in which Kaaps challenges hegemonic constructions of Afrikaans.
Formatted: Font: (Default) + Headings CS (Times New Roman), Complex Script Font: + Headings CS (Times New Roman)

Formatted: Font: (Default) + Headings CS (Times New Roman), Complex Script Font: + Headings CS (Times New Roman)

Formatted: Font: (Default) + Headings CS (Times New Roman), Complex Script Font: + Headings CS (Times New Roman)

Formatted: Font: (Default) + Headings CS (Times New Roman), Complex Script Font: + Headings CS (Times New Roman)

Formatted: Font: (Default) + Headings CS (Times New Roman), Complex Script Font: + Headings CS (Times New Roman)

Formatted: Font: (Default) + Headings CS (Times New Roman), Complex Script Font: + Headings CS (Times New Roman)

Formatted: Font: (Default) + Headings CS (Times New Roman), Complex Script Font: + Headings CS (Times New Roman)

Formatted: Font: (Default) + Headings CS (Times New Roman), Complex Script Font: + Headings CS (Times New Roman)

Formatted: Font: (Default) + Headings CS (Times New Roman), Complex Script Font: + Headings CS (Times New Roman)

Formatted: Font: Italic, Complex Script Font: Italic

Formatted: Font: (Default) + Headings CS (Times New Roman), Complex Script Font: + Headings CS (Times New Roman) 
of the resistant artist, and take as subject his incarceration on Robben Island, and the experience of exile, the remote vantage point from which he examines the injustices of the apartheid state. Brutus writes almost exclusively in English but has alluded frequently to the richness of his linguistic background. He relates to English, Afrikaans and Xhosa as all equally available, charting a fluid passage between languages, an almost nonchalant multilingualism that temporalizes the racialized cordoning off of languages as an effect of apartheid rule $(2006,165)$ : "My mother and father spoke English and Afrikaans, but we were living in a community prior to apartheid, before 1948. We had segregation, but separation was not yet enforced by law. So I could grow up speaking English, Afrikaans, and a little Xhosa, which was the African language in my area." Brutus conveys less a sense of his resentment of the hegemonic imposition of English and Afrikaans as an unapologetic intimacy with these languages, an easy possessiveness and pride in his own mastery. This adaptive plurilinguality is a hallmark of South African experience, often suppressed or denied by the regime.

In an interview with Johan van Wyk, Brutus relates to his earliest literary influences, revealing, perhaps unexpectedly, that his first poems (now lost) were written in Afrikaans. He enumerates with little irony his poetic forbears $(2000,171)$ : “[t]he way I taught myself Afrikaans was by reading Afrikaans poetry. I started reading Malherbe, van der Heever, Langenhoven and people like that - mainly to acquire the vocabulary but in the process of acquiring the vocabulary I also acquired the imagery."

Of the poets Brutus mentions, both C. J. Langenhoven and Daniel Malherbe were active in the establishment of Afrikaans as a "volkstaal," a "language of the nation," where the nation is defined exclusively as white Afrikaners. Langenhoven is perhaps best-known for composing South Africa's national anthem under apartheid, "Die Stem," an anthem which, as Nhlanhla Maake (1996, 148) claims, "not only celebrates an exclusively Afrikaner culture, language and history, but also makes a claim to all the land and space." Langenhoven (as quoted in Giliomee 2003, 369), notoriously asserting white ownership of Afrikaans, declared, “Afrikaans is our greatest possession ... the one and only white man's language which was made in South Africa... [ It is] ... the expressed soul of our volk." Malherbe, a prominent Afrikaans poet, novelist, dramatist and polemicist, like Langenhoven, played an important role in the codification of Afrikaans: Brutus' unashamed acknowledgement of their poetry as a fertile 
repository of imagery, is an unusually confident assertion of the possibility of severing the language from its ideologues.

Perhaps most strikingly, in Brutus' account of South Africa's polyphony he records that his reading of English poetry is filtered through an Afrikaans history of literature.

One of the most useful books I read of poetry was an Afrikaans book and I'm not sure I remember the title. I read the Dekker, 'Literatuur-geskiedenis' which I bought for myself as soon as I had enough money. But there was a book which was about literature and it was by an Afrikaner. It was in Afrikaans and it had a green soft binding and I learnt so much about poetry including English poetry from that book. In fact, I only understood the poetry of someone like Dante Gabriel Rosetti via an Afrikaans author. (van Wyk 2000,

The textbook, its colour and haptic materiality carefully retained in memory, in which the black poet first reads canonic English poetry in translation, becomes an icon of linguistic and cultural syncretism, of the intricate overlaying and reticulation of different codes that apartheid so strenuously contests.

Brutus only rarely allows one of South Africa's languages to cross into the text of the poems. ${ }^{4}$ However, in the 1978 volume, Stubborn Hope: New Poems and Selections from China Poems and Strains, Brutus makes particularly arresting use of Afrikaans in a short untitled poem (2006, 276) that sets his state of present exile into painful exchange with his South African past:

Here of the things I mark

I note a recurring hunger for the sun

-but this is not homesickness,

the exile's patriate thirst:

At home, in prison, under house-arrest

\footnotetext{
${ }^{4}$ The 1967 untitled poem that opens "To be thrown outward in a steel projectile" is wholly concerned with the injury of displacement. Brutus uses the Afrikaans word for an exile, "banneling," marking its derivation with inverted commas. The semantic proximity to the word "banning" functions partially as a pun, deliberately provoking a misreading for readers outside of South Africa, to produce a conflation of the exiled and the banned. Brutus' less successful 2009 poem on the rebuilding of Iraq's national museum ends with the line "Inderdaad, dit is tyd te baljarr" - a translation into Afrikaans of the previous line, "verily it is time to rejoice." Here the justification for the introduction of Afrikaans is difficult to fathom.
} 
The self-same smagting* bit me

now is the same as then

and here I live as if still there.

*Afrikaans for yearning

1978

The use of Afrikaans in a poem written by a dissident South African poet is always provocative.

Its appearance in a poem written in exile, by a poet whose work was banned within South Africa, and who could not therefore rely on a readership for whom the term would be immediately recognizable as Afrikaans and its meaning transparent or at least accessible, seems at first doubly perturbing. The perplexity that its use induces is compounded since the word "smagting" does not initially seem in any conventional sense untranslatable and its English equivalent, "yearning" does not noticeably compromise the meaning or meter of the poem. Brutus marks the word's aberrance by placing it in italics within the poem and by the asterisked translation placed outside the poem that specifically marks its provenance as Afrikaans. It is thus both untranslated and translated - its obstructive presence within the poem gesturing towards a meaning that is available but unincorporated. The strangeness of the term lies partly in the obscurity, even secrecy, of its pronunciation: the fricative "g" of "smagting" is absent in English and the auditory distinctiveness of the Afrikaans is not annotated so that its otherness is only partially mitigated by the proffered translation. Thus Brutus embeds within the poem a potential unreadability or mis-articulation that gestures towards the incomprehensibility for the outsider of the anguish of the exiled dissident. These multiple markings of alterity, the linguistic incongruence and the disruption of the discreteness of the poetic form, force a profound defamiliarization that expresses itself in an impeded reading and in the re-ordering or disordering of perception that Viktor Shklovsky (1998) identifies as defamiliarization's primary poetic effect. The poetic estrangement is put into play to summon the primary estrangement that the poem addressesthat of the South African subject in exile both within and outside South Africa.

The opening line of the poem that conjures the longing for an African sun seems to place the poem firmly within the genre of exilic poetry with its familiar evocation of a cold climate as 
metaphor for the exile's exposure and discomfort. ${ }^{5}$ Brutus consistently represents his yearning for South Africa not as a nagging but bittersweet pull backwards into a lost past, but as an acute nostalgia - that is, the specific complex of affective and physical symptoms implicit in the etymology of the word. As has been widely noted, the term derives from the Greek nostos, "return home" and algos," "pain" or "suffering." The medical origins of the term have particular pertinence for Brutus' conception of nostalgia as sickness. The injury to the self and its expression in a pathology of loss that are the sequelae of exile are almost always described in Brutus' poems as internal injuries, invisible to the observer. This occulted suffering is made explicit in poems like "To be thrown outward in a steel projectile," $(2006,250)$ where the pain of exile is depicted as "the true deep wound that lies / like the dark bruised pulp at the heart of the fruit" that manifests as an insistent if undiscerned presence, an internalized wounding, as an "acrid searing stench / that scalds the eyes / swallows up the breath / and fixes the brain in a wail."

The poem's apparent concern with the longing of the political exile for a lost place, a lost time, a lost weather from a new place in which he is made strange, is subverted in the second stanza: the swerve is marked by the dash, a caesura unusually and awkwardly placed at the beginning of the line to precipitate the rupture, and by the emphatic conjunction, "but." The speaker forcefully rejects the term "homesickness": instead, he re-names the particular biting sensation he experiences with the Afrikaans signifier, "smagting." The Afrikaans word defines the unique injury inflicted when the longing for home is endured from within the home, launched precisely from the point of proximity and intimacy. The term designates a yearning far more profound and more debilitating than exilic longing which is now only a simulacrum, indicated by the comparative "as if," of an emotion already rehearsed and refined within South Africa.

For Brutus this aporetic yearning that sets the speaker in search of a home within his home is born out of the material practices of apartheid. Its enforced unhousings and displacements, the tenuousness of ownership which transform the home into a precarious space, and the punitive carceral structures that apartheid imposes on its opponents, can only be designated in a language that is uniquely South African, that carries the history of the dispossession that it describes and

\footnotetext{
${ }^{5}$ The image appears in poems like "November sunlight silvers my grimy panes" in which the "gruel- grey sky" of England is contrasted with the South where "heat pours down / and the world glows." In the poetry of Arthur Nortje, the cold and rain of London's streets are repeatedly used as a correlate for the exile's alienation.
} 
where the claim to a right of articulation within the language is an act of defiance. Thus the sign nominally translated is, as the poem makes clear, untranslatable, since the particular syndrome of exilic longing experienced within the country rather than without, is so peculiarly localized that a translation can only approximate its meaning.

The term "smagting" signals Brutus' conception of South Africa as an uncanny space, the heimlich rendered irreparably unheimlich. As Bhabha $(1997,445)$ suggests in his reprise of Freud's uncanny in his essay "The World and the Home," the uncanny is politicized precisely at those junctures where the state forcibly enters into and lays claim to the private sphere: "the intimate recesses of the domestic space become sites for history's most intimate invasions. In that displacement, the border between home and world becomes confused; and, uncannily, the private and the public become part of each other, forcing upon us a vision that is divided as it is disorienting." In Brutus' poem, this violation of intimate space is signaled in the detailing of the loci of smagting: "At home, in prison, under house-arrest," where each place, and the signifier for each place, is compromised or debased by the depredations of apartheid, and each is hopelessly imbricated in the other. Home is the site of exile, the prison becomes the dissident's home, and house arrest transforms the home into a prison.

If the Afrikaans signifier directs us to the singular and anomalous experience of a longing predicated on proximity, it paradoxically and willfully retains the sense of desire. The word smagting reverberates to suggest that the nostos, however corrupted, is still somehow endeared, still the object of yearning. This doubled characterization of South Africa as simultaneously defaced and degraded, yet cherished, is one to which Brutus returns repeatedly. In his poem "Somehow we survive," $(1973,4)$ he expresses this duality most acutely:

\section{Somehow we survive}

and tenderness, frustrated, does not wither.

most cruel, all our land is scarred with terror,

rendered unlovely and unlovable;

sundered are we and all our passionate surrender

but somehow tenderness survives. 
That the true lineaments of the country can be discerned beneath the defacing effects of apartheid, and that these endure as the object of longing because of the possibility of their restoration in the future, is to deflect South African nostalgia away from its past. Svetlana Boym (2008, xvi) in her study The Future of Nostalgia pointedly notes that nostalgia is not always or exclusively directed backward, that it carries a prospective dimension. In "Here of the things I mark" the speaker remembers and yearns forward: to express this yearning in Afrikaans is to call into question the claim to ownership of the language by the perpetrators of apartheid and reclaim it as the black speaker's language, that is, to twin its history as the language of oppression with an imagined future where it is to be re-instated as the language of all its speakers. The signifier provocatively placed at the center of the poem does more than evoke love for a lost country or a country not yet come- its presence suggests that the object of longing is the language itself, the intimacy of the first-language speaker with the conjugations of a known vocabulary, the fit in the mouth, the familiar resonance in the ear, that render translations only paler reflections of an original, loved lexicon.

Brutus' play between translation and untranslatability evident in the oscillation of the Afrikaans signifier between mourning and desire, renders the trope of translation more layered in this poem than its conventional implementation in South African literary production. Brutus' complicates the tendency to identify Afrikaans solely with the machinery of oppression; his acknowledgement of a language prized and claimed despite its codification of apartheid destabilizes the notion of untranslatability as a metonym for the regime's intransigent resistance to mixing and its fundamental unresponsiveness to difference.

\section{"In my language there is no word for citizen": Keorapetse Kgositsile and the}

\section{untranslatable}

Kgositsile's use of untranslated Afrikaans in the poem "No Serenity Here" is perhaps even more disconcerting than Brutus' use of Afrikaans. Like Brutus, Kgositsile transports or translates Afrikaans into the poem to make apartheid obdurately present in the weave of the text. While Brutus transports apartheid's signs across geographical space from South Africa to transplant them subversively in the place of exile, Kgositsile moves Afrikaans across time, beyond apartheid's putative end, into post-apartheid South Africa. 
Kgositsile, born in a largely white area of Johannesburg in the village, Dithakong ${ }^{6}$ in-1938, became one of the ANC's prominent and vocal activists. In 1961 at the behest of the ANC, he went into exile, initially to Dar es Salaam, and subsequently to America where his involvement in and formative influence on the Black Arts Movement has been widely studied. ${ }^{7}$ In 1990 he returned to South Africa and in 2006 was appointed Poet Laureate.

$\underline{\text { Kgositsile has repeatedly attested to the force of language in his work. His English is re-formed }}$ by his own mother tongue, Setswana. On exile, Setswana is carried into the urban setting of Harlem, embedded within an English now made to nurture the memory of the speaker's past voices, in an act of linguistic miscegenation that both taunts and defeats apartheid's forced purgations and separations. Addressing the musical syncretism he meets in Harlem in "A Poets Credo", Kgositsile relates also to a linguistic polyphony: "there is nothing like art-in the oppressor's sense of art. There is only movement. Force. Creative power. The walk of $\underline{\text { Sophiatown tsotsi or my Harlem brother on Lenox Avenue. Field Hollers. The Blues. A Trane }}$ riff. Marvin Gaye or mbaqanga" ((Negro Digest, 1968: 42, quoted in Phalafala,2016 19). The playful segueing between languages and American and African musical styles epitomizes the mixing Kgositsile advocates. In his evocation of the tsotsi, the black South African gangster, Kgositsile subtly evokes Tsotsitaal, the creole of Sophiatown and other black townships,(Molamu 1995 144) a language based on Afrikaans and drawing on a variety of African languages, that undoes the myth of Afrikaans' immaculacy.

$\underline{\text { In a frequently repeated phrase, Kgositle invokes a "tamed English". By asserting an African }}$ language's capacity to alter colonial codes, he ironically reverses the repeated trope of African barbarism that must be subdued, claiming for African languages an agency that harnesses English to their own ends. "[I]f English is going to express my lived experience, my response to a life in poetry it has to be tamed to speak my language."

${ }^{6}$ I am grateful to Uhuru Phalafala (2018) for pointing out the frequent misconception that Kgosistsile was born in Johannesburg. Phalafala suggests that the confusion arises from an attempt to protect the young Kgositsile from the Group Areas Act of 1950 that restricted residence in areas designated white

${ }^{7}$ Kgositsile's involvement in the Black Arts Movement is the subject of critical works including M.N. Crawford's

"Productive Rites of Passing": Keorapetse Kgositsile and the Black Arts Movement," Tsitsi Jaji's "Sound Effects: Synaesthesia as Purposeful Distortion in Keorapetse Kgositsile's Poetry" and Uhuru Phalafala's "Black music and Pan-African Solidarity in Keorapetse Kgositsile's Poetry."

Formatted: Font: (Default) + Headings CS (Times New Roman), Complex Script Font: + Headings CS (Times New Roman) 
There is almost no evidence of Afrikaans, a language with which Kgositsile was familiar, in the poems written in exile. He relates only briefly in an interview to the ways in which dispossession is encoded into the name of the colonial usurpers: Afrikaners - of Africa, and their language, Afrikaans - the language of Africa, a nomenclature that denies the prior presence of South Africa's black inhabitants (Rowell 1978, 26). After Kgositsile's return to South Africa from exile in the aftermath of Nelson Mandela's release in 1990, he published an essay, "Crossing Borders Without Leaving," and a poem, "In the Wheeling and Dealing Time," in Staffrider, a prominent South African literary magazine identified with the resistance to apartheid (1991, 5-10, 76). In both these pieces Kgositsile's tone is somber: the euphoria of return and of homecoming is noticeably absent. Instead he emphasizes an enduring exilic consciousness, a sense of uncanniness that persists even in the last throes of apartheid rule and that is recognizable from Brutus' poems considered above. Remembrance is aborted or missing: "there are no memories here. The streets of Johannesburg cannot claim me. I cannot claim them either"(1991, 6). In an African reprise of Michel de Certeau's "Walking in the City" the flâneur despairingly confronts the massive edifices of South African capitalism in downtown Johannesburg, his circumlocutions confirming his own disorientation. In both the Staffrider poem and the essay, Kgositsile unsparingly addresses the manifestations of black violence directed towards other black South Africans, condemning the practice of necklacing by his reference to the writer Sandile Dikeni whose grandmother was murdered in this way. In these two texts the sense of some abject pollution in the polis is made manifest in Kgositsile's doubled use of the untranslated Afrikaans phrase, "daar is kak in die land," ("there is shit in the land.")

In the 2009 poem "No Serenity Here," he revives the same phrase as the poem's grieving crescendo. The poem's subject is the outbreak of xenophobic violence against African labour migrants entering post-apartheid South Africa. The attacks are perceived by Kgositsile as a betrayal of the principles of the armed struggle and its underlying vision of pan-African solidarity. His denouncement of this resurgent nationalism stands in sharp contrast to the triumphant constructions of achieved liberty, manifest in some South African post-apartheid writing.

The poem opens with a prose meditation on nationalism as a legacy of colonialism. From its outset the poem is concerned with translation and untranslatability, ranging words and languages against each other so that the exposure of post-apartheid failures is embedded in an analysis of 
linguistic abuses, equivocations and misconstruals. In an insightful analysis of the poem, Tsitsi Jaji $(2014,243)$ points to the dominance of its concern with the devices of language: "What the poem achieves ... is to performatively foreground the many ways that language does things with words - through mode, genre, line break, caesura, citation, repetition, anaphora, acronym, references to accent, and, quite starkly, switching between languages."

Far from embracing the vision of ameliorative translation proposed by Krog and others, Kgositsile construes translation as a transgressive act, a position more closely aligned to that adopted by theorists like Bassnett who draw attention to the implication of translation in postcolonial power structures, and its practice as marked by violence: "In my language there is no word for citizen which is an ingredient of the $19^{\text {th }}$ century omelette. That word came to us as part of the package that contained the bible and the rifle. But moagi, resident, is there and it has nothing to do with any border or boundary you may or may not have crossed before waking up on the piece of earth where you currently live."

In an essay "Race: What Time Is It" (2004) that anticipates the poem, Kgositsile outlines the etymology of moagi:

We speak of moagi, resident. 'Go agisana/agisanya,' from aga, from which moagi is derived, means, 'in the same breath', 'building together' and/or 'living together in harmony or peace' But we carry passports, those badges of our participation in the world of those who plundered our world and established boundaries to demarcate their property." (as quoted in Jaji 2014, 242)

The mutual untranslatability of the two terms citizen and moagi hinges on their respective predications on exclusion and inclusion, on possession and communality. If there is no word in Setswana that can convey "the exclusionary logic of citizenship" (Jaji, 242), and its embeddedness in a history of what Mark Neocleous (2003) terms "cartographic violence," the word "resident" in English, an attempt to temper the connotations of nationalism implicit in "citizen," cannot incorporate the meanings of mutuality inherent in the Setswana term. Thus the signifier "citizen" must be forcefully imposed in an act of epistemic violence so that its translation, or mistranslation, figures as an act that not only displaces or erases other meanings, but which perverts conduct.

The poem's contestations of borders and its upholding of an ethic of passages, intersections and confluences is signaled by its dense intertextuality, itself a paradigm of border crossings and 
translations. Kgositsile cites Langston Hughes' poem “Harlem,” incorporating Hughes' warning of the apocalyptic consequences of racial violence into the poem's admonition; Mazisi Kunene's Zulu epic, Emperor Shaka the Great (1979), is deferentially quoted in the poem's evocation of "a thousand thundering voices" ${ }^{8}$ raised in protest at the defilement of xenophobia; and a rich skein of African proverbs, markers of African orature, are woven into the text to evoke the panAfricanism and transcontinental solidarity that Kgositsile evokes as the antithesis of the black on black violence mourned within the poem.

While the first stanza open with an apostrophe, "Poem, I know you are reluctant to sing when there is no joy in your heart," by the final stanza the artifice of rhetorical address has been replaced by a full- throated first-person lament that is also an appeal to an ancestral history:

my mothers, fathers of my father and me

how shall I sing to celebrate life

when every space in my heart is surrounded by corpses?

whose thousand thundering voices shall I borrow to shout

once more: Daar is kak in die land!

The voicing of a prophetic rebuke in Afrikaans induces a radical subversiveness. In this late reiteration of Afrikaans, a polluted language is used to summons a lingering pollution. The violence directed against foreigners becomes, for Kgositsile, evidence of the terrifying spectrality of European nationalism and racism. As Derrida reminds us $(1985,294)$ apartheid is “a European 'creation,"” predicated on a "European 'discourse' on the concept of race." Here Afrikaans is made the metonym of apartheid and of that discourse. In the scatological castigation that ends the poem Afrikaans is positioned as a language that bears and transfers the taint of brutalization as the foul legacy of European colonization. There is no attempt to qualify the European provenance of Afrikaans or to temper its characterization as the language of oppression. It is precisely because Afrikaans is so profoundly implicated in South Africa's racial violence that it is evoked here. Indeed, the poem's deepest censure lies in its implication that Afrikaans is once again made serviceable. Ironically, the untranslated phrase that ends the poem suggests the translatability of apartheid's codes, their capacity to cross over the putative terminus of South African racism.

\footnotetext{
${ }^{8}$ Kgositsile cites Kunene's epic poem $(1979,286)$ : "There was a clanging and ripping of weapons / Thudding sounds, splashing sounds, crackling sounds / Roaring cries of a thousand voices."
} 


\section{Conclusion}

Bethlehem (2018), drawing on the work of Robyn Wagner Pacifici, has traced what she terms the "restlessness" of apartheid expressive culture as it moves beyond South Africa. Language, one of the many things that apartheid moves, in Bethlehem's resonant formulation $(2018,50)$, crosses out of South Africa and back, following exiles and the repatriated, translated both across other languages and across geographical borders. As Bethlehem notes, "itinerancy spans time as well as spaces" $(2018,50)$. This article has traced the passage of Afrikaans into exile in the poetry of Brutus and its traversal across time into post-apartheid South Africa in the post-exilic poetry of Kgositsile. The two poems considered restage the valence of Afrikaans in dissident poetry: Brutus' ambivalent and complex attachment to the Afrikaans signifier that he reclaims from apartheid's grip in "Here of the things I mark," and Kgositsile's remonstrative placing of untranslated Afrikaans in "No Serenity Here," a gesture that confounds the triumphalism of translation in the new South Africa, provide new paradigms with which to assess the tenacity and reach of the trope of translation in South African cultural production both during apartheid and in post- apartheid South Africa.

\section{Acknowledgements}

This work was supported by the European Research Council under the European Union's Seventh Framework Programme (FP/2007-2013) / ERC Grant Agreement no. 615564.

My enduring gratitude to Professor Louise Bethlehem for her insightful comments on this paper and for her assistance in refining the concerns presented here.

\section{Works Cited}

Alexander, Neville. 2009. "Afrikaans as a Language of Reconciliation, Restitution and Nation Building." In Roots conference, University of the Western Cape, Cape Town, South Africa, 22-23 https://www.litnet.co.za/afrikaans-as-a-language-of-reconciliation-restitution-and-nation/ Apter, Emily. 2013. Against World Literature: on the Politics of Untranslatability. London: Verso. Bethlehem, Louise. 2007. Skin Tight: Apartheid Literary Culture and its Aftermath. Pretoria: Unisa Press. 
Bethlehem, Louise. 2018. "Restless Itineraries: Antiapartheid Expressive Culture and

Transnational Historiography." Social Text 36(3(136)):47-69.

doi: https://doi.org/10.1215/01642472-6917766

Breytenbach, Breyten. 1978. In Africa Even the Flies Are Happy. London: Calder

Brutus, Dennis. 1973. A Simple Lust: Selected Poems including Sirens, Knuckles, Boots, Letters

to Martha, Poems from Algiers, Thoughts Abroad. London: Heineman.

Brutus, Dennis. 2006. Poetry \& Protest: A Dennis Brutus Reader. Chicago: Haymarket Books.

Bassnett, Susan. 2014. Translation. Oxon: Abingdon.

Bhabha, Homi. 1994. The Location of Culture. London: Routledge.

Bhabha, Homi. 1997. "The World and the Home.” Cultural Politics 11: 445-455.

Boym, Svetlana. 2008. The Future of Nostalgia. New York: Basic books.

Coetzee, Carli. 2013. Accented Futures: Language Activism and the Ending of Apartheid. New York: NYU Press.

Crawford, Margo Natalie. 2007. "Productive Rites of 'Passing': Keorapetse Kgositsile and the Black Arts Movement. Black Renaissance, 7(3):112-120.

De Kock, Leon. 2012.“"A Change of Tongue': Questions of Translation.” In The Cambridge

History of South African Literature, edited by Derek Attridge and David Attwell, 739-756.

Cambridge: Cambridge University Press.

Derrida, Jacques. 1985. "Racism's Last Word.” Critical Inquiry, 12(1): 290-299.

Giliomee, Hermann. 2003. The Afrikaners: Biography of a People. Charlottesville, University of Virginia Press.

Gray, Stephen, ed. 1985. The Penguin Book of Southern African Stories. London: Penguin Books.

Gray, Stephen. 1989. "Some Problems of Writing Historiography in Southern

Africa." Literator 10 (2): 16-24.

Jaji, Tsitsi. (2014). Africa in Stereo: Modernism, Music, and Pan-African Solidarity. Oxford:

Oxford University Press.

Kgositsile, Keorapetse. 1991. “Crossing Borders Without Leaving.” Staffrider, 4(2):5-10.

Kgositsile, Keorapetse. 2009. Beyond Words: South African Poetics. Defeye.

Krog, Antjie. 1998. Country of My Skull: Guilt, Sorrow, and the Limits of Forgiveness in the New South Africa. Cape Town: Random House Struik.

Krog, Antjie. 2009. A Change of Tongue. Cape Town: Random House Struik. 
Krog, Antjie, Nosisi L. Mpolweni-Zantsi, and Kopano Ratele. 2009. There Was This Goat: Investigating the Truth Commission Testimony of Notrose Nobomvu Konile. Scottsville: University of KwaZulu-Natal Press.

Kunene, Mazisi. 1979. Emperor Shaka the Great: A Zulu Epic. London: Heinemann.

Maake, Nhlanhla. 1996."Inscribing Identity on the Landscape: National Symbols in South Africa." In Text, Theory, Space, edited by Kate Darian-Smith, Elizabeth Gunner, and Sarah Nuttall, 145-154. London: Routledge.

Molamu, Louis.1995."Wietie: The Emergence and Development of Tsotsitaal in South Africa." Alternation 2, no. 2 139-158.

Neocleous, Mark. 2003. “Off the Map: on Violence and Cartography.” European Journal of Social Theory, 6(4): 409-425.

Oxford English Dictionary, s.v. “translate,” accessed July 17, 2019,

https://www.oed.com/view/Entry/204841?rskey=Z426qe\&result=2\#eid

Phalafala, Uhuru Portia. 2016. My Name is Afrika: Setswana Genealogies, Trans-atlantic

Interlocutions, and NOW-time in Keorapetse Kgositsile's Life and Work.Doctoral dissertation,

\section{University of Cape Town.}

Phalafala, Uhuru Portia. 2017. "Black music and pan-African solidarity in Keorapetse

Kgositsile's poetry.” Safundi, 18(4):307-326.

Phalafala, Uhuru Portia. 2018. “A Song of Constant Beginnings.” https://mg.co.za/article/2018-

\section{1-12-00-a-song-of-constant-beginnings}

Raditlhalo, Sam. 2009." 'Truth in Translation': The TRC and the Translation of the

Translators." Biography, 32(1): 89-101.

Rowell, Charles H. 1978. "" With Bloodstains to Testify": An Interview with Keorapetse

Kgositsile." Callaloo2: 23-42

Rushdie, Salman. 1991. Imaginary Homelands: Essays and Criticism 1981-91. London: Granta

Books.

Sanders, Mark. 2000. "Truth, Telling, Questioning: The Truth and Reconciliation Commission, Antjie Krog's Country of My Skull, and Literature after Apartheid." Modern Fiction Studies 46(1):13-41.

Shklovsky, Viktor. 1998. “Art as Technique.” In Literary Theory: An Anthology, edited by Julie Rivkind and Michael Ryan, 15-21. Mass.: Blackwell. 
Stroud, C., \& Williams, Q. 2017. Multilingualism as Utopia: Fashioning Non-racial selves. AILA Review, 30(1), 167-188.

Van Heerden, M. 2016. Afrikaaps: A Celebratory Protest against the Racialised Hegemony of 'Pure'Afrikaans. Unpublished doctoral dissertation, Stellenbosch: Stellenbosch University.

van Wyk, Johan. 2001. Interview with Dennis Brutus. Alternation, 8(2):168-215.

Venuti, Lawrence. Ed. 2019. Rethinking Translation: Discourse, Subjectivity, Ideology. London: Routledge.

Wicomb, Zoe. 2002. "Translations in the Yard of Africa." Journal of Literary Studies, 18(3-4): $209-223$.

Willemse, Hein. 1987. “The Black Afrikaans Writer: a Continuing Dichotomy.” Triquarterly 69: $236-46$.

Willemse, Hein. 2015. "The hidden histories of Afrikaans." Unpublished manuscript, University of Pretoria, South Africa. http://www.up.ac.za/media/shared/45/willemse_mistra20151105-

2_2.zp80127.pdf. 